\title{
Factors that determine shoot viability and root development during in vitro adaptation and propagation of silver birch (Betula pendula Roth)
}

\section{Miglè Vaičiukynė*,}

Jonas Žiauka,

\section{Sigutė Kuusienè}

Laboratory of Forest Plant Biotechnologies, Institute of Forestry, Lithuanian Research Centre for Agriculture and Forestry,

1 Liepu St, Girionys 53101,

Kaunas District, Lithuania
Background. Micropropagation of silver birch (Betula pendula Roth) is used to obtain healthy plant material for high-value plantations. The aim of this study was to evaluate the first steps of birch explant introduction and maintenance in vitro in order to make practical suggestions about the influence of these first steps on further micropropagation success.

Materials and methods. Of the seven studied birch genotypes, one had been cultured in vitro for two years at the time of experiments, while six were newly planted in vitro from shoot segments disinfected after either one or two weeks of storage of collected branches. The explants were placed in glass culture tubes either on a hormone-free or cytokinin (6-benzylaminopurine)-supplemented medium.

Results. A shorter branch storage time (one week instead of two) was better for the viability of explants, while external cytokinin, if used during the very first subculture in vitro, had largely a negative impact. Among the tested birch genotypes, 52BPL171 had the highest rate of viable explants and was followed in this respect by 01BPL115 which, however, contrasted strongly to the former because of its ability to maintain a green shoot apex alongside a green stem on the control medium. After 12 months in vitro, only genotype 01BPL115 was characterized by regular shoot growth and a well-developed root system.

Conclusions. The green shoot apex on the control medium and, also, maintenance of viability on the medium with external cytokinin were found to be most helpful characteristics of birch explants during the first subculture, early recognition of those genotypes that would be most promising for obtaining multiple rooting shoots in vitro.

Keywords: Betula pendula, cytokinin, in vitro culture, micropropagation

\footnotetext{
* Corresponding author. Email: m.vaiciukyne@gmail.com
} 


\section{INTRODUCTION}

Representatives of Betula (birch) genus, widespread particularly in the northern parts of Eurasia and North America, are among the most important deciduous tree species in these regions (Ryynänen et al., 2005). In the coniferousdominated forests of Northern Europe, birch species (Betula pendula and B. pubescens) often grow in mixed stands with Scots pine and Norway spruce (Rytter et al., 2014), contributing significantly to the biodiversity sustention here, since birch trees provide living room for many other life forms, such as mycorrhiza-forming fungi, herbivores, wood-decaying fungi, and saproxylic insects (Hynynen et al., 2010). Besides its ecological significance, birch is important for bioenergy production in these northern regions. Birch trees from naturally occurring and artificial plantations are also used as raw material in the manufacture of plywood and in sawmills (Ryynänen et al., 2005). Birch has a high potential for regeneration and a rapid growth rate even in poor soil; therefore it is suitable for planting in deserted agricultural lands (Walle et al., 2007) and promising for the establishement of economically valuable short rotation plantations (Hynynen et al., 2010).

Traditionally, birches are propagated either through seeds or through vegetative saplings. In the early growth stage, seedling grow much faster and, therefore, 4-5-year-old seedlings are higher than vegetative saplings. Still, birch vegetative saplings have bigger leaves, higher chlorophyll content, and thicker crown than seedlings (Kauppi et al., 1988). However, productivity and bud number of vegetatively propagated birch saplings vary and depend on the stump height and harvesting time of a parent tree (Ferm, Kauppi, 1990). Microvegetative propagation of birch, using stem explants and callus, is also an option, since micropropagated plants are more uniform in respect of height and stem volume, have less fissures, and flower earlier than seedlings (Jones et al., 1996).

Birch was one of the first forest trees involved in micropropagation experiments that were performed by Huhtinen and Yahyaoglu as early as in 1974. Historically, apices, internodes, nodes, young leaves, and axillary buds were used as explants for regeneration of $B$. pendula and B. pubescens (Huhtinen, Yahyaoglu, 1974; Chalupa, 1981; Srivastava, Steinhauer, 1981; Simola, 1985; Ryynanen, Ryynanen, 1986). Currently, in vitro studies of birch continue to be carried out and focus largely on improvement of micropropagation conditions (Kontsevaya, 2009) and on investigation as to how environmental factors may influence rooting (Bojarczuk, 2000; Wynne et al., 2002) and general plant morphology (Ryynänen et al., 2005). The results of such studies can contribute to more effective establishment of short-term stands of birch and to further biotechnological manipulations with birch tissues and cells. Particularly, microshoot culture techniques are actual for the accumulation of healthy reproductive material since birch dieback-causing fungal pathogens pose a potential danger to birch stands (Green, MacAskill, 2007).

Since birch genetic variability studies recommend involving more traits (e.g. wood hardness) in selection programmes (Baliuckienè, Baliuckas, 2006), genotype performance in vitro can also be considered as one of practically important traits. Therefore, it is important to involve a larger number of birch genotypes in micropropagation studies in order to see what infuence genotype may have on explant viability and performance in vitro, particularly, at the start of in vitro culture. Accordingly, the present study involved seven $B$. pendula genotypes and followed largely the first steps of explant introduction and maintenance in vitro with the aim of making practical suggestions about the influence of these first steps on further micropropagation success.

\section{MATERIALS AND METHODS}

\section{Plant material and growth conditions}

Experiments were conducted on clones of seven Betula pendula Roth genotypes selected in Lithuania. One of the genotypes was originally a rotfree tree from the birch seed stand of Satkūnai forest enterprise (Joniškis district). The explants of this tree were introduced to in vitro culture in 
2014, two years before the other six genotypes. The latter were taken from the seed orchard of $B$. pendula, established from selected birch tree clones in the nursery of Dubrava Experimental and Training Forest Enterprise. The characteristics of the original donor trees of these six genotypes are given in Table 1. Their explants were introduced to in vitro culture in 2016.

In experiments, the microshoot culture method was used as described by Ahuja (1987). In all the cases, Woody Plant Medium (WPM; Lloyd, McCown, 1980) basal salt mixture (Sigma-Aldrich Chemie GmbH, Germany), supplemented with a standard amount of WPM vitamins, $20 \mathrm{~g} \cdot \mathrm{L}^{-1}$ sucrose and $3.95 \mathrm{~g} \cdot \mathrm{L}^{-1}$ gelrite (all produced by Duchefa Biochemie, the Netherlands), was used as a standard nutrient medium. The $\mathrm{pH}$ value of the medium was set at 4.8 before gelrite addition and autoclavation (30 min at $121^{\circ} \mathrm{C}$ ). As a control medium, it was hormone-free; only for particular experiments or for particular culture stages, the medium was supplemented with a cytokinin-type growth regulator - 6-benzylaminopurine (BAP; SigmaAldrich Laborchemikalien GmbH, Germany). BAP was first dissolved in $0.5 \mathrm{ml}$ of $\mathrm{NaOH}$ and then diluted with distilled water to $100 \mathrm{ml}$ volume. This solution was filtered using a $0.22 \mu \mathrm{m}$ syringe-driven filter prior to adding it (at the ap- propriate volume) to the autoclaved nutrient medium. In all the cases when BAP was used, its concentration in the medium was $24 \mu \mathrm{mol} \cdot \mathrm{L}^{-1}$.

Glass culture tubes $(150 \mathrm{~mm}$ height and $20 \mathrm{~mm}$ diameter), each containing $5 \mathrm{ml}$ of medium, were used for culturing of individual birch explants. Standard controlled environment conditions were maintained during the experiments: $16 \mathrm{~h}$ photoperiod (photon flux density $30 \mu \mathrm{mol} \mathrm{m}^{-2} \mathrm{~s}^{-2}$ ) and $25 / 18^{\circ} \mathrm{C}$ (day/ night) temperature regime.

\section{Birch explant introduction to in vitro culture} Introduction of the six birch genotypes (Table 1) to aseptic in vitro culture was done in early spring. First, branches with ready-to-burst vegetative buds were cut from the tree crowns. The collected branches were immersed into containers with water at room temperature. For experimental purposes, the branches from each tree were divided into two groups which differed from each other in respect of the time span between branch collection and explant introduction to in vitro culture. This varied branch storage time was either one or two weeks. After that time, approximately $2 \mathrm{~cm}$ long apical stem segments of young shoots, carrying two to three buds (including an apical bud), were collected from branches and prepared for

Table 1. Original donor trees of birch genotypes that were introduced to in vitro culture in 2016

\begin{tabular}{|c|c|c|c|c|}
\hline \multirow{2}{*}{$\begin{array}{l}\text { Tree code in the database of Lithu- } \\
\text { anian State Forest Service (2015) }\end{array}$} & \multirow{2}{*}{$\begin{array}{c}\text { Coordinates } \\
\text { (forest enterprise) }\end{array}$} & \multicolumn{3}{|c|}{ Tree characteristics in 2015} \\
\hline & & Age, years & Height, m & Diameter, m \\
\hline 49BPL073 & $\begin{array}{c}55^{\circ} 06^{\prime} \text { ŠP; } 24^{\circ} 22^{\prime} \mathrm{RI} \\
\text { (Pageležiai) }\end{array}$ & 100 & 28 & 0.45 \\
\hline 51BPL088 & $\begin{array}{c}54^{\circ} 47^{\prime} \text { ŠP; } 24^{\circ} 4^{\prime} \text { RI } \\
\text { (Šilènai) }\end{array}$ & 65 & 28 & 0.43 \\
\hline 01BPL115 & $\begin{array}{c}56^{\circ} 16^{\prime} \text { ŠP; } 24^{\circ} 48^{\prime} \mathrm{IR} \\
\text { (Spalviškiai) }\end{array}$ & 50 & 34.5 & 0.35 \\
\hline 20BPL125 & $\begin{array}{c}55^{\circ} 42^{\prime} \text { ŠP; } 24^{\circ} 23^{\prime} \mathrm{RI} \\
\text { (Vainagiai) }\end{array}$ & 60 & 32 & 0.40 \\
\hline 52BPL171 & $\begin{array}{c}54^{\circ} 47^{\prime} \text { ŠP; } 23^{\circ} 38^{\prime} \mathrm{RI} \\
\text { (Šališkiai) }\end{array}$ & 70 & 33 & 0.44 \\
\hline 22BPL195 & $\begin{array}{c}55^{\circ} 07^{\prime} \text { ŠP } ; 21^{\circ} 53^{\prime} \mathrm{RI} \\
\text { (Pagègiai) }\end{array}$ & 65 & 28 & 0.35 \\
\hline
\end{tabular}


introduction to in vitro culture. Before being transferred onto the nutrient medium, these explants were disinfected with $50 \%$ commercial bleach Ace (Dalli Production Romania SRL) for 2 min, commercial bactericid Bacticid (AS Chemi-Pharm, Estonia) for $3 \mathrm{~min}$, and 75\% ethanol (Stumbras, Lithuania) for 2 min. After each of these treatments, the explants were two times washed with disinfected distilled water: first time for $1 \mathrm{~min}$ and second time for $3 \mathrm{~min}$. Afterwards, they were placed onto disinfected (autoclaved) WPM in closed culture tubes.

During the first 12 days of in vitro culture, the explants of each of the six genotypes were divided between control and BAP-supplemented media for experimental purposes. After this initial period and until the third month in vitro, the frequency of explant subculturing was one week, which was prolonged to one month afterwards. After the first four months in vitro, all remaining explants were transferred onto the medium with BAP to induce callus formation until being planted on the control medium again five months later. The overall scheme of explant culture conditions during 12-months period is given in Table 2 .

\section{Reaction of in vitro-established birch cul- tures to external cytokinin}

The influence of BAP was further evaluated during comparison of birch genotypes 01BPL115 (selected among the newly introduced genotypes for its superior in vitro performance) and

Table 2. Culture conditions for Betula pendula explants during 12-months period after introduction to in vitro culture

\begin{tabular}{c|c|c}
\hline $\begin{array}{c}\text { Period (from } \\
\text { the start of } \\
\text { culture) }\end{array}$ & $\begin{array}{c}\text { Subculture } \\
\text { frequency }\end{array}$ & $\begin{array}{c}\text { Nutrient } \\
\text { medium }\end{array}$ \\
\hline 12 days & - & Control BAP ${ }^{1}$ \\
\hline $\begin{array}{c}13 \text { days }- \\
2 \text { months }\end{array}$ & 7 days & Control \\
\hline $3-4$ months & 1 month & Control \\
\hline $5-9$ months & 1 month & BAP \\
\hline $10-12$ months & 1 month & Control \\
\hline${ }^{1}$ BAP -6 -benzylaminopurine $\left(24 \mu \mathrm{mol} \cdot \mathrm{L}^{-1}\right)$
\end{tabular}

43BSM001 (introduced in vitro two years earlier than the other six genotypes). Previous to the experiment, explants of the both genotypes were cultured on a hormone-free medium for a period of three months. The experiment involved control (hormone-free) and BAP-supplemented media. Each treatment consisted of three replications, 20 explants per replication, and these were organized in a completely randomized design. The results (shoot length and shoot and root numbers per explant) were recorded after six weeks of explant culture on the experimental media.

\section{Statistics}

For the comparative analysis of experimentally obtained rates and means, a two-tailed Welch's t-test intended for use with samples having possibly unequal variances (Welch, 1947) was performed in Microsoft Excel 2010, calculating the probability $(\mathrm{P})$ that two separate samples come from populations with the same mean. The results given in rates (e.g., a rate of explants with a certain characteristic) were also treated as means of binomial distribution for statistical purposes. A difference between experimental variants is considered significant if an obtained $\mathrm{t}$-test result is $P<0.05$.

\section{RESULTS}

\section{Introduction of birch explants to in vitro culture}

After 12 days following the introduction to in vitro culture, the average rate of infected explants varied among individual birch genotypes from 0 (01BPL115, 20BPL125, 52BPL171, 22BPL195, 51BPL088, 49BPL073) to $80 \%$ (22BPL195). In some of the genotypes, infection rate was found to be dependent on the storage time between cutting of branches from a donor tree and disinfection of explants (Fig. 1A). The most dramatic difference $(P<0.001)$ in this respect was observed in genotype 22BPL195: no explant of this genotype got infected if storage time was just one week but the infection rate reached $80 \%$ if storage time was prolonged to two weeks. Interestingly, genotype 01BPL115 
was the only one which caught some infection (20\%) when the explants were disinfected after one week of branch storage, although no infection was observed among the explants of this genotype if the branches were stored for two weeks. However, the negative effect of prolonged branch storage time before explant introduction to in vitro culture was even more clearly revealed by the rates of brown (signifying the loss of viability) explants. In four of the studied six genotypes, the rate of brown explants was significantly higher if the branches were stored for two weeks, in comparison to one-week storage (Fig. 1B). The differences were most significant $(P<0.001)$ in genotypes 01BPL115 and 20BPL125 that had relatively small rates of browning explants (20\%) if the storage time was one week but lost most or even all (genotype 20BPL125) explants to browning in the case of two-weeks storage.

Following the observed negative effect of prolonged storage time on explant viability, the re-

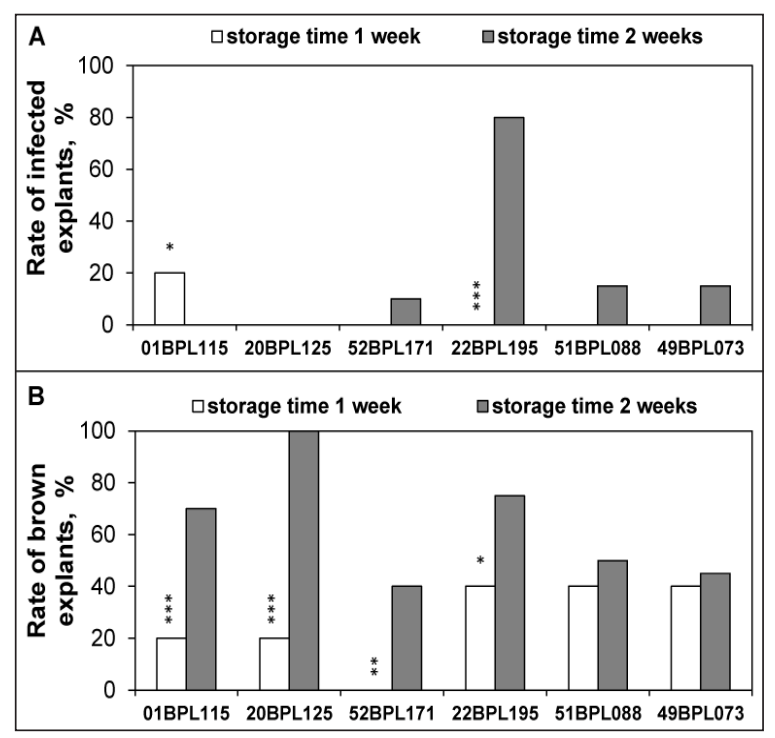

Fig. 1. Rates of infected (A) and brown (B) explants in different Betula pendula genotypes following 12 days after introduction in vitro on a hormonefree medium. "Storage time" refers to a time span between collecting of branches from the trees and disinfection of explants. Significant differences between the tested storage times are labeled: ${ }^{\star}(P<0.05),{ }^{* *}(P<0.01),{ }^{* *}(P<0.01)$ sults described further in the text consider only those explants that were introduced in vitro after one week of storage. Instead, the supplement of nutrient medium with cytokinin BAP $\left(24 \mu \mathrm{mol} \cdot \mathrm{L}^{-1}\right)$ is taken into account here. Among different genotypes, the average rates of explants with a green stem (after 12 days in vitro) varied from $60 \%$ (22BPL195, 51BPL088, 49BPL073) to $100 \%$ (52BPL171) on the hormone-free medium (Fig. 2A) and from 0 (51BPL088, 49BPL073) to $80 \%$ (52BPL171) on the medium with BAP (Fig. 2B). Thus, during this first stage of in vitro culture, BAP proved as a negative factor for explant viability. However, even on the hormonefree medium, only a part of the explants with a green stem had a green apex as well. For instance, although all the explants of genotype 52BPL171 had a green stem, only $20 \%$ of them had a green apex (Fig. 2A). Meanwhile, genotypes 01BPL115 and 51BPL088 were distinguished from the other genotypes by the fact that all their explants with a green stem had

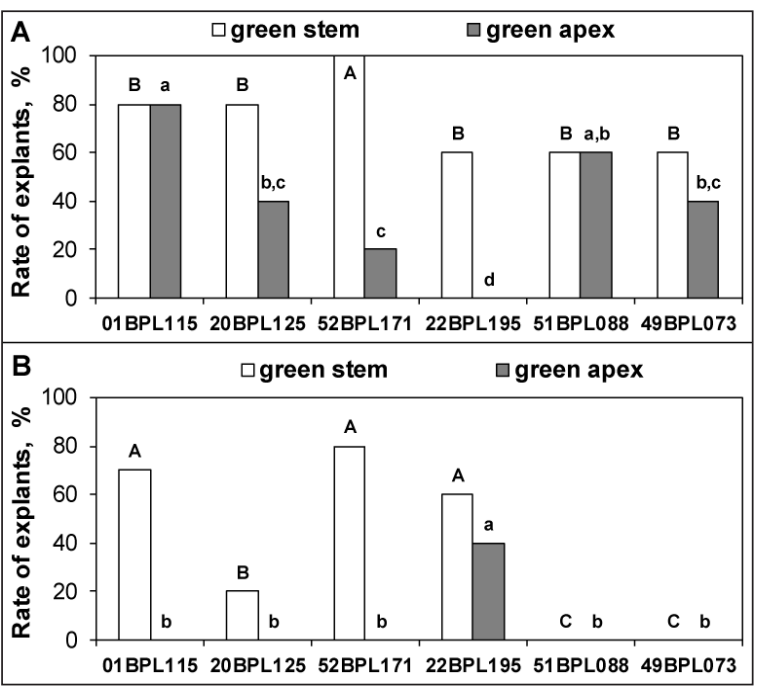

Fig. 2. Rates of green explants in different Betula pendula genotypes following 12 days after introduction in vitro on a hormone-free medium (A) or a medium with $24 \mu \mathrm{mol} \cdot \mathrm{L}^{-1}$ of 6-benzylaminopurine (B). Birch genotypes labeled with the same letter do not differ significantly $(P<0.05)$ from each other. Upper-case letters signify differences in respect of explants with a green stem and lower-case letters - of explants with a green apex 
a green apex as well. Thus, genotype 01BPL115 was the one with the highest rate of green apices $(80 \%)$ on the hormone-free medium. Interestingly, genotype 22BPL195 was the only one of the six tested genotypes, whose explants (40\%) had green apices on the medium with BAP (Fig. 2B) but not on the hormone-free medium.

In summary, large differences in explant viability were found among the tested birch genotypes. Genotype 52BPL171, having the highest rate of explants with a green stem on both hormone-free and BAP-supplemented media, was followed in this respect by genotype 01BPL115. The explants of the latter, however, contrasted strongly to those of 52BPL171 on the control medium because of their ability to maintain a green shoot apex alongside a green stem (Fig. 2A). These two genotypes differed clearly also in their morphogenetic patterns. Although both had very similar rates of explants with developed leaves (45-50\%, while the other genotypes varied in this respect from 20 to $40 \%$ ), secondary shoot development was found only in genotype 52BPL171 (50\% against 0 in 01BPL115; Fig. 3). With no secondary shoot development, genotype 01BPL115 was inferior in this respect not only to 52BPL171 but also to 20BPL125 (20\%). Besides 01BPL115, there were two other genotypes - 51BPL088 and 49BPL073 - without secondary shoots on the control medium. Interestingly, these two were the same genotypes whose

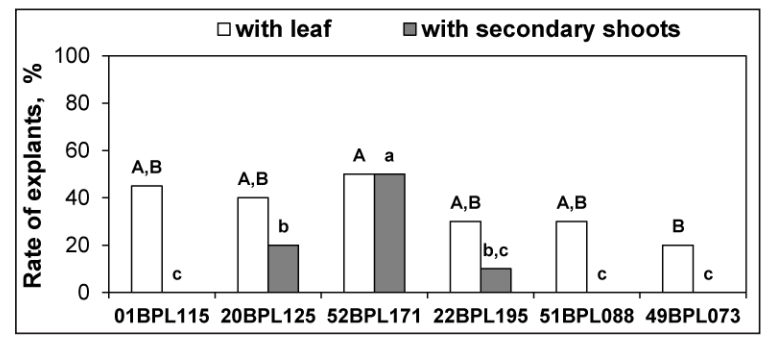

Fig. 3. Rates of explants with particular morphological structures in different Betula pendula genotypes after 12 days on a hormone-free medium. Birch genotypes labeled with the same letter do not differ significantly $(P<0.05)$ from each other. Upper-case letters signify differences in respect of explants with leaves and lower-case letters - of explants with secondary shoots viability was most negatively affected by BAP treatment, resulting in the absence of green explants (Fig. 2B).

\section{Callus induction, shoot regeneration, and rooting}

After four months following the introduction of birch explants to in vitro culture, all surviving explants of all the genotypes were transferred onto a medium containing $24 \mu \mathrm{mol} / \mathrm{l}$ of BAP. This step was taken for callus induction. After two months on the medium with BAP, all the explants of genotypes 51BPL088 and 49BPL073 had become brown and not suitable for further culture. Meanwhile, the other genotypes (01BPL115, 20BPL125, 52BPL171, and 22BPL195) formed callus that was cultured on BAP-supplemented medium for three additional months. After this period, the results showed that regeneration of new shoots from callus occurred only in genotypes 01BPL115 and 52BPL171. Accordingly, only these two genotypes remained in the culture and were able to produce new shoots continuously. However, the differences between the two were sharp: after 12 months in tissue culture, genotype 01BPL115 was characterized by regular shoot growth and well-developed root system, while genotype 52BPL171 regenerated from callus relatively weak shoots that largely did not form roots (Table 3). Interestingly, although genotype 01BPL115 had a 5.6 times higher propagation rate than 52BPL171 (if all viable explants after the first 12 -days subculture in vitro were considered as starting material), the rates between the total number of explants after 12 months and the number of explants with a green apex after the first 12 days were quite similar in both genotypes (Table 3 ).

Root-forming genotype 01BPL115 (characterized in this particular experiment by $4.05 \pm 0.46$ primary adventitious roots and $8.14 \pm 1.38$ secondary roots per explant) was compared to yet another Betula pendula genotype - 43BSM001 - that was established in vitro two years earlier but usually did not form roots on the control medium. In order to see how these two genotypes differ in their 
Table 3. Explant propagation results in two Betula pendula genotypes after 12 months following the introduction to sterile in vitro culture

\begin{tabular}{l|c|c|c|c}
\hline Genotype & $\begin{array}{c}\text { Total } \\
\text { number of } \\
\text { explants }\end{array}$ & $\begin{array}{c}\text { Rate of rooted ex- } \\
\text { plants (from the to- } \\
\text { tal number), } \%\end{array}$ & $\begin{array}{c}\text { Propagation rate } \\
\text { (from the number of } \\
\text { viable explants after } \\
\text { the first 12-days } \\
\text { subculture in vitro) }\end{array}$ & $\begin{array}{c}\text { Rate between the total number } \\
\text { of explants after 12 months } \\
\text { and the number of explants } \\
\text { with a green apex after the first } \\
\text { 12-days subculture in vitro }\end{array}$ \\
\hline 01BPL115 & 201 & 88.1 & 6.7 & 12.6 \\
\hline 52BPL171 & 44 & 2.3 & 1.2 & 11.0 \\
\hline
\end{tabular}

reactions to exogenous cytokinin, the experiment again involved explants planted on different nutrient media: control and supplemented with $24 \mu \mathrm{mol} \cdot \mathrm{L}^{-1}$ BAP. BAP caused a significant $(P<0.001)$ decrease in average shoot length and increase in shoot number per explant in the case of genotype 01BPL115 but did not affect these characteristics in 43BSM001 (Fig. 4A-B). However, the latter genotype, even on the control medium, had 5.4 times higher number of shoots per explant than 01BPL115. In regard to rooting, a total inhibitory effect of BAP could be observed only in genotype 01 BPL115 (Fig. 4C), since 43BSM001 did not form roots on either medium.

\section{DISCUSSION}

In earlier in vitro studies of factors determining the viability of Betula pendula explants, attention was largely given to the effects of certain environmental and chemical treatments conducted on already established in vitro cultures (Bojarczuk et al., 2000; Wynne et al., 2002). However, the present study showed that also pretreatment conditions of collected plant material, e.g. storage time between cutting of branches and explant preparation, can have a decisisive influence on ex-

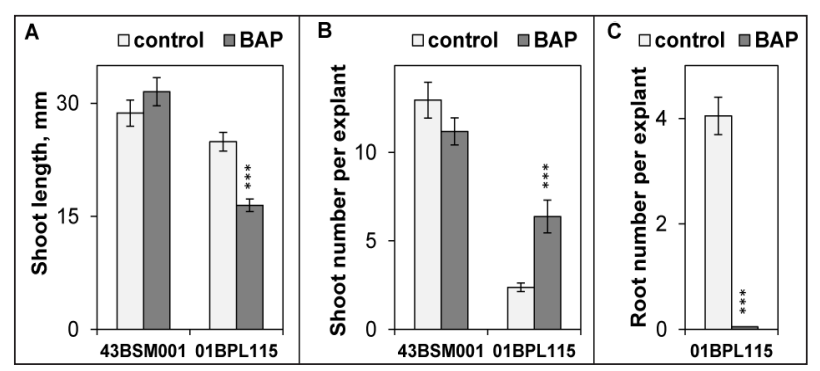

plant viability in vitro. Furthermore, such a genotype-dependent trait as presence of green shoot apices during the first subculture of explants was found to be an important factor for the determination of which fate awaits a given birch genotype in vitro, considering, particularly, its potential for rooting. This observation might be associated with natural auxin, since this hormone is known to be synthesized largely in young leaves around a shoot apex (Ljung et al., 2001) and, once transported through cambium downwards, able to stimulate adventitious rooting on the basal part of a stem (Blilou et al., 2005; Petrasek, Frimley, 2009). This generally accepted model of auxin synthesis, transport and action in plants provides a possible explanation as to how the maintenance of a green shoot apex during the very first subculture in vitro could have contributed to the effective realisation of rooting potential in the particular birch genotype - 01BPL115 - during later stages of tissue culture.

Although most of the early studies on B. pendula micropropagation recommend the use of cytokinin-type growth regulators not only for the multiplication but also for the introduction of birch material in vitro (Chalupa et al., 1981; Ditmar, 1991; Huetteman et al., 1993), the present findings suggest that better results in re-

Fig. 4. Morphological characteristics - shoot length (A), shoot number (B) and root number (C) per explant (mean $\pm \mathrm{SE})$ - in two Betula pendula genotypes on different nutrient media (BAP - medium supplemented with $24 \mu \mathrm{mol} \cdot \mathrm{L}^{-1}$ of 6-benzylaminopurine). Significant differences between samples cultured on different media are labeled with $^{* * *}(P<0.001)$ 
spect of explant viability during the very first in vitro subculture can be achieved on cytokininfree nutrient medium, since the numbers of viable explants and, particularly, of those with a green shoot apex were reduced in most of the tested genotypes if medium was supplemented with BAP. The loss of a green shoot apex under the influence of BAP might be associated with auxin-cytokinin crosstalk, since it was found by other authors (Marhavý et al., 2011) that increased amount of cytokinin leads to a decrease of auxin efflux proteins in plant cell membrane. Such interference with auxin transport might have led to an increased auxin concentration in shoot apex of BAP-treated birch explants, resulting in apex browning because of herbicidal action of local auxin excess (auxin ability to act as a herbicide is described in detail by Kraft et al. (2007)).

It is interesting that those genotypes of birch that remained viable and multiplied shoots in vitro but were unable to form roots (52BPL171 and 43BSM001) developed on the control medium in a pattern similar to that of root-forming genotype 01BPL 115 under cytokinin treatment, resulting not only in the absence of roots but also in increased number of shoots per explant. Thus, difficult-to-root birch genotypes seemed to experience cytokinin-like inluence even on the control medium. Internally produced or accumulated cytokinin might have contributed to this phenomenon. Although the role of the main biosynthesis site of plant cytokinins is attributed to root tip (Aloni et al., 2005), shoot apex is also known, e.g. from an early study of asparagus (Yasunori et al., 1980), to produce cytokinin during in vitro culture. Meanwhile, the question about hormone production and balances in different birch genotypes remains open for further research.

\section{CONCLUSIONS}

From the practical results of the present study, it can be concluded that storage time of Betula pendula branches between collection in the field and explant disinfection and introduction to in vitro culture should not exceed one week, since prolonged storage time (two weeks) resulted in a significant loss of explant viability. External cytokinin (BAP) had no positive impact on explant viability if used during the first in vitro subculture of birch explants; however, in later culture stages, callus formation and new shoot regeneration were obtained in some of the tested birch genotypes on the BAP-supplemented medium. Two characteristics of explants during the first subculture were found to be particularly indicative, seeking to recognize early those birch genotypes that would be most promising for obtaining multiple rooting shoots in vitro: green shoot apex on the control medium and, also, maintenance of viability on the medium with external cytokinin.

\section{ACKNOWLEDGEMENTS}

The present research findings have been obtained through the long-term research programme "Sustainable Forestry and Global Changes" implemented by the Lithuanian Research Centre for Agriculture and Forestry.

Received 28 July 2017

Accepted 12 September 2017

\section{References}

1. Ahuja MR. In vitro propagation of poplar and aspen. Cell Tissue Cult Forest. 1987; 3: 207-23.

2. Aloni R, Langhans M, Aloni E, Dreieicher E, Ullrich CI. Root-synthesized cytokinin in Arabidopsis is distributed in the shoot by the transpiration stream. J Exp Bot. 2005; 56: 1535-44.

3. Baliuckienè A, Baliuckas V. Genetic variability of silver birch (Betula pendula L.) wood hardness in progeny testing at juvenile age. Baltic Forest. 2006; 12: 134-40.

4. Blilou I, Xu J, Wildwater M, Willemsen V, Paponov I, Friml J, et al. The PIN auxin efflux facilitator network controls growth and patterning in Arabidopsis roots. Nature. 2005; 433: 39-44. 
5. Bojarczuk K. Effect of aluminium on in vitro rooting of birch (Betula pendula Roth.) and poplar (Populus tremula L. $\times$ P. Alba L.) microcuttings. Acta Soc Bot Pol. 2000; 69(4): 251-5.

6. Chalupa V. In vitro propagation of birch (Betula verrucosa Ehrh.). Biol. Plant. 1981; 23: 472-4.

7. Ditmar O. In vitro regeneration of Curly birch, Betula pendula var. carelica. Thaiszia, Košice. 1991; 1: 119-24.

8. Ferm A, Kauppi A. Coppicing as a means for increasing hardwood biomass production. Biomass. 1990; 22: 107-21.

9. Green S, MacAskill GA. Pathogenicity of Marssonina betulae and other fungi on birch. Plant Pathol. 2007; 56: 242-50.

10. Huetteman CA, Preece JE. Thidiazuron: a potent cytokinin for woody plant tissue culture. Plant Cell Tiss Org. 1993; 33(2): 105-19.

11. Huhtinen O, Yahyaoglu ZB. Das frühe Blühen von aus Kalluskulturen herangezogenen Pflänzchen bei der Birke (Betulu pendula Roth) Silvae Genet. 1974; 23: 32-4. German.

12. Hynynen J, Niemistö P, Viherä-Aarnio A, Brunner A, Hein S, Velling P. Silviculture of birch (Betula pendula Roth and Betula pubescens Ehrh.) in northern Europe. Forestry. 2010; 83(1): 103-19.

13. Jones OP, Welander M, Waller BJ, Ridout M. Micropropagation of adult birch trees: production and field performance. Tree Physiol. 1966; 16: 521-25.

14. Kauppi A, Kiviniitty M, Ferm A. Growth habits and crown architecture of Betula pubescens Ehrh. of seed and sprout origin. Can. J. For. Res. 1988; 18: 1603-23.

15. Kontsevaya II. Dlitelnoe khranenie mikrorasteniy berezy $\mathrm{v}$ kulture tkaney [Long-term maintenance of birch microplants in tissue culture]. Lesovedenie. 2009; 5: 50-6. Russian.

16. Kraft M, Kuglitsch R, Kwiatkowski J, Frank M, Grossmann K. Indole-3-acetic acid and auxin herbicides up-regulate 9-cis-epoxycarotenoid dioxygenase gene expression and abscisic acid accumulation in cleavers (Galium aparine):
Interaction with ethylene. J Exp Bot. 2007; 58(6): 1497-503.

17. Ljung K, Bhalerao RP, Sandberg G. Sites and homeostatic control of auxin biosynthesis in Arabidopsis during vegetative growth. Plant J. 2001; 28: 465-74.

18. Lloyd G, McCown BH. Commercially-feasible micropropagation of mountain laurel, Kalmia latifolia, by use of shoot-tip culture. Int Plant Prop Soc Proc. 1980; 30: 421-6.

19. Marhavý P, Bielach A, Abas L, Abuzeineh A, Duclercq J, Tanaka H, et al. Cytokinin modulates endocytic trafficking of PIN1 auxin efflux carrier to control plant organogenesis. Dev Cell. 2011; 21: 796-804.

20. Petrasek J, Friml J. Auxin transport routes in plant development. Development. 2009; 136: 2675-88.

21. Rytter L, Karlsson A, Karlsson M, Stener L-G. Skötsel av björk, al och asp. Skogsskötselserien, Skogsstyrelsen, Jönköping; 2014; 131 p. Swedish.

22. Ryynänen L, Aronen T. Genome fidelity during short- and long-term tissue culture and differentially cryostored meristems of silver birch (Betula pendula). Plant Cell Tiss Org. 2005; 83: 21-32.

23. Ryynanen L, Ryynanen M. Propagation of adult curly-birch succeeds with tissue culture. Silva Fenn. 1986; 20: 139-47.

24. Simola LK. Propagation of plantlets from leaf callus of Betulaa pendulu $f$. purpurea. Scientia Hortic. 1985; 26: 77-85.

25. Srivastava PS, Steinhauer A. Regeneration of birch plants from catkin tissue cultures. Plant Sci Lett. 1981; 22: 379-86.

26. Walle IV, Van Camp N, Van de Casteele L, Verheyen K, Lemeur R. Short-rotation forestry of birch, maple, poplar and willow in Flanders (Belgium) II. Energy production and $\mathrm{CO}_{2}$ emission reduction potential. Biomass Bioenerg. 2007; 31(5): 276-83.

27. Welch BL. The generalization of "Student's" problem when several different population variances are involved. Biometrika. 1947; 34(1-2): 28-35. 
28. Wynne J, McDonald MS. Adventitious root formation in woody plant tissue: The influence of light and indole-3-butyric acid (IBA) on adventitious root induction in Betula Pendula. In Vitro Cell Dev-Pl. 2002; 38(2): 210-2.

29. Yasunori K, Yozo O. Cytokinin production by Asparagus shoot apex cultured in vitro. Physiol. Plant. 1980; 49: 193-7.

Miglè Vaičiukynė, Jonas Žiauka, Sigutė Kuusienė

KARPOTOJO BERŽO (BETULA PENDULA ROTH) ADAPTACIJĄ IN VITRO BEI ŪGLIỤ DAUGINIMO METU GYVYBINGUMĄ IR ŠAKNŲ VYSTYMĄSI LEMIANTYS VEIKSNIAI

\section{Santrauka}

Beržo (Betula pendula Roth) mikrodauginimas padeda gauti sveiką augalinę medžiagą našioms plantacijoms ịveisti. Šio darbo tikslas - iqvertinti pirmus beržo eksplantų įdejjimo ir palaikymo in vitro kultūroje etapus bei pateikti praktines pastabas apie šių etapu ịtaką tolesnei mikrodauginimo sèkmei. Tirti septyni beržo genotipai: vienas iš jų i in vitro kultūrą buvo įdètas prieš dvejus metus iki vykdomų eksperimentų, kiti šeši tyrimo metu įdèti ị in vitro kultūrą iš ūglių segmentų, surinktų nuo savaitę arba dvi palaikytų ir dezinfekuotų šakų. Eksplantai buvo įdèti î stiklinius mègintuvèlius ant terpès be hormonų arba su citokininu 6-benzilaminopurinu. Trumpesnis šakų laikymo laikotarpis (viena savaitè) buvo palankesnis eksplantų gyvybingumui, o citokininas, panaudotas pirmoje in vitro subkultūroje, daugiausia turejo neigiamą poveikį. Iš visų tirtų beržo genotipu 52BPL171 turejo didžiausią gyvybingų eksplantų dali, nuo jo nedaug atsiliko 01BPL115 genotipas. Vis dèlto šis genotipas stipriai skyrèsi nuo pirmojo savo gebẻjimu išlaikyti ne tik žalią stiebą, bet ir žalią ūglio viršūnę ant kontrolinès terpès. Po dvylikos mẻnesiu in vitro kultūroje vien tik 01BPL115 genotipas pasižymèjo stabiliu ūglių augimu ir geru šaknų sistemos vystymusi. Taigi galima daryti išvadą, jog žalia ūglio viršūnè ant kontrolinès terpès, taip pat gebejjimas išlaikyti gyvybingumą ant terpès su citokininu yra svarbiausios beržo eksplantų savybès, $\mathfrak{i}$ kurias reikia atsižvelgti siekiant anksti identifikuoti tuos genotipus, iš kurių tolesniame mikrodauginimo etape būtų galima gauti gerai besišaknijančius ūglius.

Raktažodžiai: Betula pendula, citokininas, in vitro kultūra, mikrodauginimas 